Author has nothing to disclose with regard to commercial support.

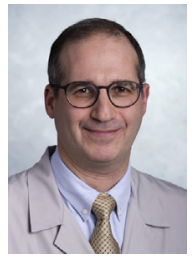

\section{PATIENTS WHO ARE DEAD BY NEUROLOGIC CRITERIA (BRAIN DEAD) ARE NOT HOMOGENEOUS}

\section{To the Editor:}

I read with great interest the article by Jawitz and colleagues ${ }^{1}$ regarding survival of hearts transplanted after death by neurologic criteria (brain death). One perhaps key factor was not included in the analysis. Patients who irreversibly lose neurologic function are not pathophysiological homogeneous. Although these patients all arrive at a state of irreversible loss of function, they do not take the same path to that outcome. Perhaps the classic case is that of a patient with a supratentorial mass, such as a hematoma, who has increased intracranial pressure, transtentorial hemorrhage, and resulting brain stem compromise. Other patients have the reverse, with primary brain stem pathology, such as a tumor or a hemorrhage, causing loss of function as a result of direct brain stem damage, with or without hydrocephalus and the resulting increase in intracranial pressure. Another set of patients could have diffuse neuronal but not glial damage as a result of hypoxia or poisoning of some type. In these patients, the loss of neurologic function is due to direct neuronal cell loss, and there may not be a significant elevation in intracranial pressure. It would not be surprising if each of these pathophysiologies results in varied amounts of sympathetic storm and resulting cardiac dysfunction. Furthermore, experimental models show that the velocity of changes in intracranial pressure is predictive of the amount of sympathetic storm. ${ }^{2}$ To obtain as data that are as useful as possible, I suggest that future studies take into account the path to loss of neurologic function and also the rate of changes of intracranial pressure.

Noam Stadlan, $M D$ Division of Neurosurgery University of Chicago

\footnotetext{
The Editor welcomes submissions for possible publication in the Letters to the Editor section that consist of commentary on an article published in the Journal or other relevant issues. Authors should: $\bullet$ Include no more than 500 words of text, three authors, and five references. • Type with double-spacing. • See http://jtcs.ctsnetjournals.org/ misc/ifora.shtml for detailed submission instructions. • Submit the letter electronically via jtcvs.editorialmanager.com. Letters commenting on an article published in the JTCVS will be considered if they are received within 6 weeks of the time the article was published. Authors of the article being commented on will be given an opportunity of offer a timely response ( 2 weeks) to the letter. Authors of letters will be notified that the letter has been received. Unpublished letters cannot be returned.
}

Pritzker School of Medicine

Chicago, Ill

Division of Neurosurgery

NorthShore University HealthSystem

Evanston, Ill

\title{
References
}

1. Jawitz OK, Raman V, Barac YD, Anand J, Patel CB, Mentz RJ, et al. Influence of donor brain death duration on outcomes following heart transplantation: a United Network for Organ Sharing Registry analysis. J Thorac Cardiovasc Surg. April 30, 2019 [Epub ahead of print].

2. Shivalkar B, Van Loon J, Wieland W, Tjandra-Maga TB, Borgers M, Plets C, et al. Variable effects of explosive or gradual increase of intracranial pressure on myocardial structure and function. Circulation. 1993;87:230-9.

\section{https://doi.org/10.1016/j.jtcvs.2019.07.143}

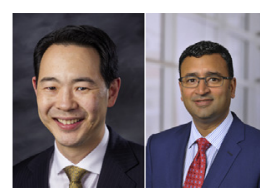

\section{REPLY: WORTH THE WAIT \\ Reply to the Editor:}

In a recent study in The Journal of Thoracic and Cardiovascular Surgery, Jawitz and colleagues reported that survival after heart transplantation is not affected by the duration of donor brain death. ${ }^{1}$ We commented in our editorial commentary that this supported allowing donor hearts more time to recover from any cardiac dysfunction they might have had, with the ultimate goal being to expand the pool of suitable donor hearts. ${ }^{2}$ In this issue, in a letter to the editor, Stadlan makes the valid point that brain-dead organ donors are not pathophysiologically homogenous, and therefore the paths leading to brain death are different. ${ }^{3}$ The suggestion is that this might also lead to different degrees of sympathetic storm and resultant cardiac dysfunction.

Numerous studies have validated the observation that patients who become brain dead are commonly subjected to cardiac dysfunction. Up to $90 \%$ of these patients have some electrocardiogram abnormalities, whereas $17 \%$ to $39 \%$ have some enzymatic leak, and approximately $14 \%$ to $18 \%$ have severe left ventricular dysfunction. ${ }^{4}$ Several mechanisms for cardiac dysfunction after brain death have been proposed, the most prominent of which is a catecholamine or sympathetic storm. A catecholamine surge after brain death has been well documented, and is implicated in the myocardial necrosis, coronary spasms, myofibrillar degeneration, and oxygen-derived free radical generation that can be seen in these hearts. ${ }^{4}$ However, cardiac dysfunction after neurological insult resolves with normalization of catecholamine levels. ${ }^{5}$

Regardless of the mechanism of brain death, what is most relevant regarding the suitability of the heart for donation is its ultimate function at the time of procurement. If, as shown by the article by Jawitz and colleagues, waiting longer before heart donation does not negatively affect 